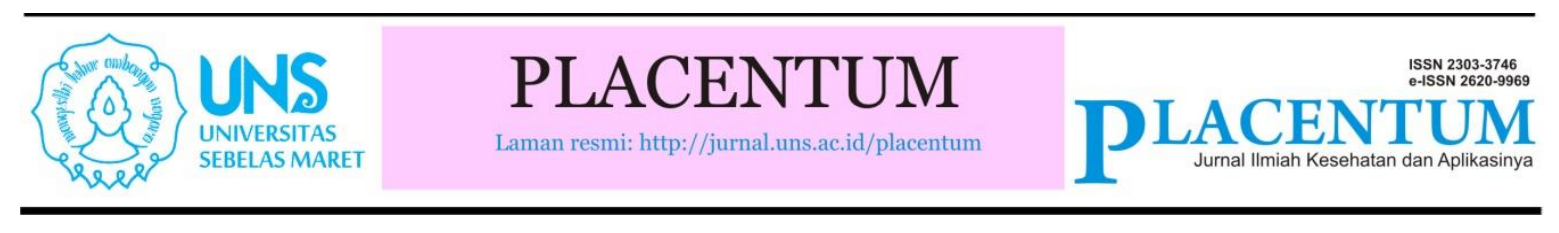

\title{
PENCEGAHAN PENYEBARAN COVID-19 MELALUI PROMOSI KESEHATAN
}

\section{Prevention of the Spread of COVID-19 through Health Promotion}

\author{
Sri Mulyani \\ ${ }^{*}$ Prodi Sarjana Terapan Kebidanan, SV, Universitas Sebelas Maret, Jl. Ir. Sutami 36A, Kentingan Surakarta 57126 \\ telp. (0271) 662622 \\ E-mail: yaniartha@yahoo.com
}

\begin{abstract}
ABSTRAK
Latar Belakang: Pemerintah Provinsi Jawa Tengah mengumumkan kasus COVID-19 mencapai 12 kasus per tanggal 20 Maret 2020. Kabupaten Klaten menjadi salah satu kabupaten yang terkena dampak KLB COVID-19. Pemerintah Kabupaten Klaten telah mengambil langkah optimal sebagai upaya pencegahan. Penetapan status KLB ini diikuti dengan himbauan Pemerintah Kabupaten Klaten agar masyarakat tidak takut dan tidak panik, serta tetap menerapkan prinsip PHBS sehingga masyarakat akan tetap aman. Pemerintah Kabupaten Klaten juga meminta warganya yang berada di luar wilayah Klaten untuk sementara waktu tidak kembali ke Klaten. Tujuan Penelitian: menganalisis efektivitas upaya promosi kesehatan untuk pencegahan penyebaran COVID-19.

Subjek dan Metode: Penelitian dilakukan pada masyarakat dan kader kesehatan di Kecamatan Kalikotes Kabupaten Klaten. Metode yang digunakan adalah kuesioner pre dan post test secara daring serta media edukasi berupa video dan gambar seputar COVID-19. Kuesioner dibuat berdasarkan analisis masalah yang dikaji dengan metode PAHO dan link disebarkan melalui tokoh masyarakat. Analisis menggunakan deskriptif persentase.

Hasil penelitian: Hasil analisis menunjukkan bahwa nilai signifikansi $0.000<0.05$ sehingga menandakan adanya perbedaan pengetahuan sebelum dan sesudah dilakukan intervensi berupa sosialisasi HATMA SEMAR.

Kesimpulan: Terdapat perbedaan pengetahuan sebelum dan sesudah dilakukan intervensi berupa video. Pengetahuan yang dimiliki seseorang atau kelompok atau budaya tertentu yang dihasilkan dari semua proses, baik bawaan dari lahir maupun yang didapatkan melalui pengalaman.
\end{abstract}

Kata Kunci: COVID-19, promosi kesehatan, pencegahan. 


\begin{abstract}
Background: The Central Java Provincial Government announced 12 cases of COVID-19 as of March 20, 2020. Klaten Regency is one of the districts affected by the COVID-19 outbreak. The Klaten Regency Government has taken optimal steps as a preventive measure. The determination of the KLB status was followed by an appeal from the Klaten Regency Government so that the community was not afraid and did not panic, and continued to apply the PHBS principle so that the community would remain safe. The Klaten Regency Government has also asked its citizens who are outside the Klaten area to temporarily not return to Klaten. Research Objective: to analyze the effectiveness of health promotion efforts to prevent the spread of COVID-19.

Methods: The research was conducted on the community and health cadres in Kalikotes District, Klaten Regency. The methods used are online pre and post test questionnaires and educational media in the form of videos and pictures about COVID-19. The questionnaire was created based on an analysis of the problems studied using the PAHO method and the links were distributed through community leaders. The analysis used a descriptive percentage.

Results: The results of the analysis show that the significance value is $0.000<0.05$, which indicates a difference in knowledge before and after the intervention in the form of HATMA SEMAR socialization.

Conclusion: There are differences in knowledge before and after the intervention in the form of video. Knowledge possessed by a certain person or group or culture that results from all processes, both innate and acquired through experience.
\end{abstract}

Keywords: COVID-19, health promotion, prevention

\section{PENDAHULUAN}

Status atau derajat kesehatan masyarakat salah satunya bisa diukur melalui angka kesakitan atau morbiditas. Angka kesakitan menggambarkan kejadian penyakit dalam satu populasi pada kurun waktu tertentu ${ }^{[1]}$. Berdasarkan penelusuran pelaksana masyarakat Kabupaten Klaten sebagai mitra binaan pengabdian memiliki dugaan beberapa masalah dalam program penunjang pembangunan kesehatan, khususnya dalam menghadapi KLB COVID-19, diantaranya:
1) kurangnya pengetahuan masyarakat terhadap KLB COVID-19; 2) kurangnya antusiasme masyarakat dalam menyikapi KLB COVID-19; 3) kurangnya pemahaman dalam berperilaku hidup sehat dan bersih dalam menghadapi KLB COVID-19; dan 4) kurangnya kesiapsiagaan masyarakat dalam menghadapi wabah atau tanggap bencana wabah KLB COVID-19 ${ }^{[2]}$. 


\section{SUBJEK DAN METODE \\ Kuesioner dibuat dan disesuaikan dengan analisis masalah yang dikaji. Kuesioner dirancang sesederhana mungkin sehingga memudahkan masyarakat termasuk kader kesehatan dalam memahami isi pertanyaan dan masyarakat tidak jenuh atau bingung dalam menjawabnya. Link kuesioner akan disebarkan pada tokoh-tokoh kunci di setiap kelompok masyarakat agar memastikan kuesioner dijawab oleh semua lapisan masyarakat.}

Kelompok masyarakat yang menjadi target harus memiliki minimal smartphone dengan sistem android maupun IOS sehingga dapat secara langsung mengisi form digital tersebut. Data diperoleh dari 21 orang kader dan 14 orang masyarakat. Data yang diperoleh dianalisis sesuai dengan tahapan yang dilakukan. Tahap 1 berupa pengkajian data awal dilakukan kepada 21 orang kader dan 14 orang masyarakat. Data tahap 1 dianalisis dengan menggunakan analisis deskriptif persentase, yaitu melihat skor ratarata, nilai maksimum dan minimum. Tahap 2 berupa pengambilan data sebelum dan sesudah dilakukan promosi kesehatan pencegahan COVID-19 berupa video.

\section{HASIL}

Tabel 1. Distribusi Karakteristik Responden berdasarkan Umur

\begin{tabular}{lcccccc}
\hline \multirow{2}{*}{ Umur } & \multicolumn{3}{c}{ Kader } & \multicolumn{3}{c}{ Masyarakat } \\
\cline { 2 - 7 } & Frekuensi & $\%$ & \% Kumulatif & Frekuensi & $\%$ & \% Kumulatif \\
\hline 17-25 tahun & 0 & 0,0 & 0,0 & 1 & 7,1 & 7,1 \\
26-35 tahun & 5 & 23,8 & 23,8 & 8 & 57,2 & 64,3 \\
36-45 tahun & 8 & 38,1 & 61,9 & 2 & 14,3 & 78,6 \\
46-55 tahun & 7 & 33,3 & 95,2 & 1 & 7,1 & 85,7 \\
56-65 tahun & 1 & 4,8 & 100 & 2 & 14,3 & 100 \\
\hline Jumlah & $\mathbf{2 1}$ & $\mathbf{1 0 0}$ & & $\mathbf{1 4}$ & $\mathbf{1 0 0}$ & \\
\hline
\end{tabular}

Tabel 2. Distribusi Karakteristik Responden berdasarkan Jenis Kelamin

\begin{tabular}{lcccccc}
\hline \multirow{2}{*}{ Jenis } & \multicolumn{3}{c}{ Kader } & \multicolumn{3}{c}{ Masyarakat } \\
\cline { 2 - 7 } Kelamin & Frekuensi & $\%$ & \% Kumulatif & Frekuensi & $\%$ & \% Kumulatif \\
\hline Laki-laki & 0 & 0 & 0 & 1 & 7,1 & 7,1 \\
Perempuan & 21 & 100 & 100 & 13 & 92,9 & 100 \\
\hline Jumlah & $\mathbf{2 1}$ & $\mathbf{1 0 0}$ & & $\mathbf{1 4}$ & $\mathbf{1 0 0}$ & \\
\hline
\end{tabular}


Tabel 3. Distribusi Karakteristik Responden berdasarkan Tingkat Pendidikan

\begin{tabular}{lcccccc}
\hline \multirow{2}{*}{ Pendidikan } & \multicolumn{3}{c}{ Kader } & \multicolumn{3}{c}{ Masyarakat } \\
\cline { 2 - 7 } & Frekuensi & $\%$ & \% Kumulatif & Frekuensi & $\%$ & \% Kumulatif \\
\hline SMP & 2 & 9,6 & 9,6 & 1 & 7,2 & 7,2 \\
SMA & 15 & 71,4 & 81 & 5 & 35,7 & 42,9 \\
Diploma/Sarjana & 4 & 19,0 & 100 & 8 & 57,1 & 100 \\
\hline Jumlah & $\mathbf{2 1}$ & $\mathbf{1 0 0}$ & & $\mathbf{1 4}$ & $\mathbf{1 0 0}$ & \\
\hline
\end{tabular}

Tabel 3. Distribusi Karakteristik Responden berdasarkan Pekerjaan

\begin{tabular}{lcccccc}
\hline \multirow{2}{*}{ Pekerjaan } & \multicolumn{3}{c}{ Kader } & \multicolumn{2}{c}{ Masyarakat } \\
\cline { 2 - 7 } & Frekuensi & $\%$ & \% Kumulatif & Frekuensi & $\%$ & \% Kumulatif \\
\hline Ibu Rumah tangga & 20 & 95,2 & 95,2 & 6 & 42,8 & 42,8 \\
Guru / dosen & 0 & 0 & 95,2 & 4 & 28,6 & 71,4 \\
Karyawan swasta & 0 & 0 & 95,2 & 2 & 14,3 & 85,7 \\
Lainnya (pedagang, & 1 & 4,8 & 100 & 2 & 14,3 & 100 \\
mahasiswa, & & & & & & \\
pendamping sosial) & & & & & & \\
\hline Jumlah & $\mathbf{2 1}$ & $\mathbf{1 0 0}$ & & $\mathbf{1 4}$ & \\
\hline
\end{tabular}

Tabel 3. Distribusi Karakteristik Responden berdasarkan Pengetahuan

\begin{tabular}{lccccccc}
\hline \multirow{2}{*}{ Pengetahuan } & \multicolumn{3}{c}{ Kader } & \multicolumn{3}{c}{ Masyarakat } \\
\cline { 2 - 8 } & Frekuensi & $\%$ & $\%$ Kumulatif & Frekuensi & $\%$ & \% Kumulatif \\
\hline Baik (76-100) & 17 & 80,9 & 80,9 & 12 & 85,6 & 85,6 \\
Cukup (56-74) & 4 & 19,1 & 100 & 2 & 14,2 & 100 \\
\hline Jumlah & $\mathbf{2 1}$ & $\mathbf{1 0 0}$ & & $\mathbf{1 4}$ & $\mathbf{1 0 0}$ & \\
\hline
\end{tabular}

Pengkajian data tahap 1 didapatkan dari 21 kader dan 14 masyarakat. Tabel 1-5 menunjukkan distribusi frekuensi berdasarkan karakteristik responden, meliputi umur, jenis kelamin, tingkat pendidikan, pekerjaan, serta pengetahuan. Tabel 4.1 menunjukkan bahwa mayoritas umur kader berada pada rentang 36-45 tahun, yaitu 8 orang $(38,1 \%)$ sedangkan minoritas berada pada rentang umur 56-65 tahun, yaitu 1 orang $(4,8 \%)$. Mayoritas umur masyarakat berada pada rentang 26-35 tahun, yaitu 8 orang $(57,2 \%)$ sedangkan minoritas berada pada rentang umur 17-25 tahun dan 46-55 tahun, yaitu 1 orang $(7,1 \%)$. Tabel 4.2 menunjukkan bahwa mayoritas jenis kelamin kader perempuan, yaitu 21 orang (100\%) dan mayoritas jenis kelamin masyarakat juga 
perempuan, yaitu 13 orang $(92,9 \%)$. Tabel 4.3 menunjukkan bahwa mayoritas pendidikan kader berada pada jenjang pendidikan SMA, yaitu 15 orang $(71,4 \%)$ dan mayoritas pendidikan masyarakat berada pada jenjang pendidikan diploma atau sarjana, yaitu 8 orang $(57,1 \%)$. Tabel 4.4 menunjukkan bahwa mayoritas pekerjaan kader sebagai ibu rumah tangga, yaitu 20 orang $(95,2 \%)$ dan mayoritas pekerjaan masyarakat juga sebagai ibu rumah tangga, yaitu 6 orang (42,8\%). Tabel 4.5 menunjukkan bahwa mayoritas pengetahuan kader berada pada kategori baik, yaitu 17 orang $(80,9 \%)$ dan mayoritas pengetahuan masyarakat berada pada kategori baik, yaitu 12 orang $(85,6 \%)$. Hasil pengisian kuesioner menunjukkan bahwa jawaban yang diberikan responden dari beberapa item pertanyaan belum terjawab dengan benar, antara lain pada item pertanyaan yang berkenaan dengan gejala, alur pemeriksaan, upaya pencegahan dan isu fakta atau hoax seputar covid-19. Hasil analisis menunjukkan bahwa adanya perbedaan pengetahuan sebelum dan sesudah dilakukan intervensi berupa video.

\section{PEMBAHASAN}

Hasil analisis menunjukkan bahwa mayoritas responden berada pada masa dewasa awal.
Masa dewasa awal merupakan masa pencarian kemantapan dan masa reproduktif ${ }^{[3]}$. Masa dewasa awal adalah suatu masa yang penuh dengan masalah dan ketegangan emosional, periode komitmen dan ketergantungan, periode isolasi sosial, perunahan nilai-nilai, penyesuaian diri pada pola hidup yang baru dan kreativitas. Pada masa ini motivasi untuk meraih sesuatu yang diinginkan sangatlah besar didukung dengan kekuatan fisik yang prima sehingga pada masa dewasa awal kekuatan fisik lebih diutamakan daripada kekuatan rasio dalam menyelesaikan suatu masalah ${ }^{[4]}$.

Pengelompokkan daftar masalah yang ada dan yang ditemukan adalah sebagai berikut: 1) Kurangnya pengetahuan tentang gejala COVID-19, 2) Kurangnya pencegahan penyebaran COVID-19 (konsep sinar matahari membunuh virus, minum jamu / empon-empon menangkal COVID-19, minum air putih banyak menangkal covid19), 3) Kurangnya pencegahan penyebaran COVID-19 (isolasi mandiri, protokol kesehatan, menghindari kerumunan), 4) Kurangnya pengetahuan mengenai alur penatalaksanaan kasus COVID-19, 5) PHBS belum dilaksanakan secara optimal, 5) Kurangnya sosialisasi di tingkat RT/RW dari sumber terpercaya, 6) Kurangnya informasi 
berkaitan dengan keberadaan masyarakat rentan, 7) Kurangnya kesadaran diri masyarakat yang pulang dari zona merah untuk isolasi mandiri ${ }^{[5][6][7]}$. Dari daftar masalah diatas akan dilakukan pemetaan untuk prioritas masalah dengan menggunakan PAHO (Pan American Health Organization $)^{[8]}$.

\section{KESIMPULAN}

Terdapat perbedaan pengetahuan sebelum dan sesudah dilakukan intervensi berupa video. Pengetahuan yang dimiliki seseorang atau kelompok atau budaya tertentu yang dihasilkan dari semua proses, baik bawaan dari lahir maupun yang didapatkan melalui pengalaman.

\section{DAFTAR PUSTAKA}

1. Mubarak, W.I. 2012. Ilmu Kesehatan Masyarakat. Jakarta: Salemba Medika.

2. Bai, et.al. 2020. Presumed Asymtomatic Carrier Transmission of Covid-19. Research Letter. Diupload tanggal 21 Februari 2020. Diakses tanggal 8 Februari 2020. https://jamanetwork.com/journals/jama/a rticle-abstract/2762028.

3. Dinkes Klaten. 2019. Profil Kesehatan Tahun 2018. Diakses tanggal 8 April 2020. http://dinkes.klatenkab.go.id/wpcontent/uploads/2019/10/PROFILKESEHATAN-KLATEN-TAHUN2018.pdf.

4. Zhou, W, et.al. 2020. Buku Panduan Pencegahan Coronavirus. 101 Tips
Berbasis Sains yang dapat menyelamatkan Hidup Anda. Chief Physician of Wulan Center For Disease Control and Prevention.

5. untuk Kebidanan. Jakarta: Salemba Medika.

6. National authorities. 2020. Coronavirus disease 2019 (COVID-19) Situation Report-67. Diakses tanggal 8 April 2020. https://apps.who.int/iris/bitstream/handle /10665/331613/nCoVsitrep27Mar2020eng.pdf.

7. Debora, Y. 2020. Update Corona di Jateng per 20 Maret, ODP hingga Positif Covid-19. Diupload tanggal 20 Maret 2020. Diakses tanggal 7 April 2020. https://tirto.id/update-corona-dijateng-per-20-maret-odp-hingga-positifcovid-19-eGpz.

8. Reber, A.S dan Reber, E.S. 2010. Kamus Psikologi. Yogyakarta: Pustaka Pelajar. 